INDEPENDENT JOURNAL OF MANAGEMENT \& PRODUCTION (IJM\&P)

http://www.ijmp.jor.br

v. 7, n. 1, January - March 2016

ISSN: 2236-269X

DOI: 10.14807/ijmp.v7i1.376

\title{
IMMUNITY TO TECHNOLOGY DIFFUSION: PLANNED TECHNOLOGY AND UNPLANNED ADAPTATION
}

\author{
Raj Kumar Bhattarai \\ Nepal Commerce Campus, Faculty of Management Tribhuvan \\ University, Nepal \\ E-mail: raj.bhattarai@outlook.com
}

Submission: 04/10/2015

Revision: 28/10/2015

Accept: 30/10/2015

\section{ABSTRACT}

The phenomena of technology transfer and adaptation are not only compelling elements of the business environment for managerial commitment, but also the manageable fit and acceptance of the phenomena with the principal actors in the structural settings that are immune to change. Effectiveness of technology diffusion primarily depends on the process of its transfer and acceptance of the principal actors in the structural settings for its adaptation.

This paper analyzes the technology planning priorities of the government of Nepal by covering the period of the last fifty years of the country's planned economy at one part and examines the organizational/structural settings for technology diffusion on the other. An extensive overview of national plan documents determines the government's planning priorities and initiatives for technology diffusion in the country. Examination of the organizational settings in the country indicates the degree of congruence between the planning priorities and arrangement for organizational settings in the enduring process of technology diffusion. An analysis of the response of opinion leaders from selected organizations involved in technology works/projects supplements to the analysis and conclusion of the study. This study concludes with an identification of unplanned organizational settings remaining as a structural immunity to the planned technology diffusion in the country. 
DOI: 10.14807/ijmp.v7i1.376

Keywords: technology planning. technology diffusion. organizational setting. structural immunity. technology adaptation.

\section{INTRODUCTION}

Structural settings and technology diffusion in a country are prerequisites and reciprocals of each other. In this study, structural setting refers to the set of organizations or institutions working in the area of technology absorption, development and transfer. The process of technology dissemination, transfer, and absorption in multiple areas like infrastructure, socioeconomic, governance, and compliance sectors of an economy refers the diffusion of technology.

An assimilation of national technology planning priorities and functional priorities of the organizations working in the areas of technology dissemination and transfer is a condition of technological advancement in a country. The process of technology diffusion is an integration of the priorities with the working priorities of the technology adopters.

The instrumentality of organizations involving in the process of technology diffusion needs to be assessed at different levels of analysis. It is necessary to understand the dialectical relationships between the forces of conflict, coercion, and disruption at one level and forces of consensus, unity, and integration at another level of the organization (ASTLEY; VAN DE VEN, 1983).

Organizations and their leaders master the immunity to change which will be dominant in their functional areas. They will set the standard in terms of accomplishing their own goals and they will have the greatest loyalty and commitment of their internal constituents (KEGAN; LASKOW LAHEY, 2009). There may be incongruence between the national technology planning priorities and the priorities of the adopting organizations involved in technology diffusion process.

In the context like Nepal, where government presence in the economy is nominal but the private and non-government sectors are enjoying freedom for the establishment and operationalization of organizations in the areas of their own choice, diffusion of technology as intended in the national plan documents is in limbo. Unplanned permission for organization establishment increases the number of organizations but it does not assimilate the technology planning priorities and functional priorities of the adopter organizations. The organizations develop their own 
DOI: 10.14807/ijmp.v7i1.376

structural immunity with strong commitment to their own constituencies or stakeholders. The immunity does not only prevent the organization in bringing change but remains incompatible with the intended change initiatives and planning priorities.

\subsection{Statement of the Problem}

In pursuance of self-reliance, Nepal developed technological capabilities in some specific areas such as agriculture, civil engineering, architecture, metallurgy, water management, medicine, textile and paper manufacture, dyeing and food technology (SINGH; BHUJU, 2001) in its own way until the beginning of her planned economy. Traditional technologies like constructing religious artifacts, images, and temples; construction of temples, pagodas, and stupas; textiles using handlooms; handmade paper; brewing wine and hard liquor; preserving meats, fruits, and vegetables $(\mathrm{JOSHI}, 2007)$ were in practice during the period.

Modern science and technology began along with the beginning of the planned economy. The country has made only a little progress in a few areas like biogas, biomass, micro-hydropower, solar energy, software development, construction materials, and food processing.

Although, science and technology systems in Nepal still need much more structural improvement in almost all the sectors like infrastructure, socioeconomic, governance and compliance. In view of the statement, this paper concentrates on the two major problems. The one is to get insight into the technology planning priorities during the planned economic efforts of more than 50 years; and the second one is to examine the technology planning priorities and structural settings aligned for the technology diffusion.

\subsection{Objectives}

The study argues that diffusion of technology represents the cumulative number of adopters of a new product, material, or process in a particular society. It follows S-shaped curve and needs an integrated efforts of all the socio-industrial actors. It is passing through various channels to the socioeconomic sector of a nation. Similarly, the study further argues that an alignment between the structural and organizational settings and national technology priorities is essential in order to 
DOI: 10.14807/ijmp.v7i1.376

develop and diffuse the technology because organizations are the carrier of the technology as well. More specifically, the objectives of the study are:

a) To examine the technology planning priorities during the planned economic efforts of more than 50 years; and

b) To ascertain the alignment between technology planning priorities and structural settings for the technology diffusion.

The results of this study provide ample evidences and illustrations to the policy makers and planners that the phenomena of technology transfer and adaptation are not only compelling elements of the business environment for managerial commitment, but also the manageable fit and acceptance of the phenomena with the principal actors in the structural settings that are being immune to change.

\subsection{Methods}

This study overviewed technology planning priorities of Nepal covering the period from 1956 to 2013. An overview of 5849 plus pages of the periodic plan and review documents of Nepal had been completed in order to determine the planning priorities for technology diffusion in the country. An exploration on the organizational settings had been made to identify the major organizations involved in the process of technology diffusion.

Overview of the objectives and working areas of the selected organizations was also done in order to ascertain their functional priorities. Unstructured interviews with selected opinion leaders associated with one or more of such organizations at different point of time were also incorporated while determining the reasons of structural immunity to change.

Overview of the plan and review documents determined the technology diffusion priorities and initiatives as well as achievements in technology branding, grading, and diffusion in the country. Subsequent exploration of the organizations found some major works/projects aiming at technology development/diffusion in different sectors in different ways. The opinion leaders' response complemented the discussion section as well. 
DOI: 10.14807/ijmp.v7i1.376

Triangulation of the planning priorities, initiatives, and responses of the opinion leaders over the works/projects of their organizations had been made in order to determine the structural immunity to technology diffusion in the country.

\section{ANALYSIS}

Technology advancement program in less developed countries like Nepal is influenced by the diffusion of imported technology. The adaptation process of a new technology encounters structural barriers like sociocultural, psychological, and economical in due course of its diffusion (PANDEY; YADAMA, 1992).

Institutional interdependence, mainly between the organizations involved in training, education, research and development and the technology adopters as well as supporting services industry actors are derailing the process of technology diffusion in the less developed country. It has been argued that role of the regulators and government officials in bringing these two sets of institutions and actors needs to be consultative and participative instead of authoritative one.

\subsection{National Periodic Plan Documents}

Nepal adopted planned economy from the beginning of second half of the twentieth century (NPC, 2012). The technology planning priorities concentrated into two paths of technology diffusion. The first one is to develop and diffuse the indigenous technology and the second one is to transfer-in already developed technology from developed countries. The priority of Nepal was on both the paths of developing the indigenous technology and transfer-in of foreign technology as well.

\section{a) First Plan (1956 - 1961)}

Technology and capital equipment considered key factors in the growth of production. The Plan assumed that improvement of economic condition within the country was depending upon knowledge of technology and expanded programs in education. Until the end of the first plan, there were nine institutions in the field of technical knowledge and skills development in the country, and 6351 persons were getting education and training in different fields.

\section{b) Second Plan (1961 - 1965)}

Technical knowledge shortage was realized sharply and high emphasis was given on technical training. Low and medium level skills training was intended to 
DOI: 10.14807/ijmp.v7i1.376

deliver within the country and foreign countries were sought for higher-level training. The country was receiving technical assistance from foreign countries and agencies namely America, India, China, Russia, Britain, Australia, Switzerland, New Zealand, Canada, United Nations, and Ford Foundation as well during the period.

In the first and second plans, special attention was given for the establishment of experimental farms and livestock centers and the training of middle-grade technicians. During the second plan period, 680 middle-grade technicians were trained and sent them to the districts.

\section{c) Third Plan (1965 - 1970)}

Technology transfer/diffusion was sought in the field of agriculture in order to replace the primitive practices. Agriculture extension to date had not been very successful because of the lack of transport facilities, technicians, and coordination with other developmental programs, improved seeds, fertilizer, credit, and efficient administration.

Decentralization of authority was in priority and the government agencies (Panchayats) were expected to handle the tasks of developing and/or diffusing technical skills. High emphasis was on the vocational and adult education. Most of the high-level technicians like doctors, engineers, and agriculture specialists were receiving education and training in India. Technical assistance for private sector development was assured and high priority was on the production of food grains. Technical assistance for training facilities, transport development, storage as well as private sector development was quite laudable during the period.

\section{d) Fourth Plan (1970 - 1975)}

Expansion of foreign trade considered as a mean of obtaining capital goods and technical expertise. Labor-intensive technology and use of indigenous resources had been realized as an important vehicle for employment generation. It was expected that the use of labor-intensive technology would bring multiplier effects in the economy. Emphasis was given to the technical education especially in the fields such as engineering, health, education, and commerce.

Several technical and vocational training centers were opened during the period; however, foreign assistance was sought in order to train the personnel in 
DOI: 10.14807/ijmp.v7i1.376

technical fields. Research programs in agriculture sectors were considered to be carried out as an integrated way of various units- agricultural botany, agronomy, agricultural engineering, entomology, plant pathology, soil science, etc. Emphasis was on the production of agriculture sector technicians like Junior Technician (JT) and Junior Technical Assistant (JTA) in district agriculture offices.

Lead farmer training program, food research program, and forestry programs were much more desired at that time. The World Bank group was expected to conduct technical and economic feasibility survey for roads throughout the country. Technical experts and equipment were sought from the United Nations for the development of telecommunications facilities. Computer technology was introduced from the year 1971 and National Computer Center was established in 1974.

\section{e) Fifth Plan (1975 - 1980)}

Encouragement of labor-intensive techniques and extensive rural works programs were major concentration of the plan. Emphasis was given for the development of technical manpower from concerned institutions in the field of engineering, medicine, agriculture, and so on.

\section{f) Sixth Plan (1980 - 1985)}

Development and use of technology involving biogas, solar energy, wind power, and natural gas was emphasized. Maximum use of local skills and technology was desired in the implementation of development project.

The plan intended to improve technology in the area of breed development of calves, bulls, buffaloes, goats, sheep, chicken, fish, and fingerlings was expected to disseminate very soon. Emphasis was put on the development of practical production technology that had immediate relevance to the problems confronting the farmers.

Intention of labor-intensive technology and job creation was continuous. Drug research and productivity improvement of the cottage industries were also emphasized in the Plan. There was also encouragement to adopt foreign technology and capital in the extraction of mineral deposits as well as establishment of mineral processing industries.

The plan intended to adopt cost efficient technology in connection with the construction of small hydel projects. Similarly, maximum use of labor-intensive 
DOI: 10.14807/ijmp.v7i1.376

technology and development of construction technology, which would permit maximum use of locally available construction materials was emphasized.

This Plan specified national science and technology objective, policy and program for the first time in the history of planned economy of Nepal. The objectives were focused to increase capability of national science and technology that would enable to embrace the entire development processes of the country, to inform the people at large on the use and utility of science and technology, and to maintain coordination among the different units that were engaged in developing and extending science and technology.

\section{g) Seventh Plan (1985 - 1990)}

This plan intended to expand and diversify the export market by enhancing competitiveness of exportable goods from the adoption of high technology and own skills as well. It was assumed that judicious use of science and technology would shift the dependence from agriculture to industries.

The Plan set objective of developing science and technology in the same pace as that of economic and social development of the country. The objectives included as upgrading the capability of science and technology by developing scientific and technical manpower, conducting research and development activities, transfer of know-how on organizational development and management; and expanding the use of science and technology by bringing awareness among the people.

The plan intended to make amendments and changes in imported technology in order to suit the local needs as well as manpower training for the use of appropriate science and technology. It was expected that indigenously developed technology would be further tested for its improvement and people would be informed about the concept, utility, and importance of science and technology in their daily lives.

The attempt of transfer of technology to the cottage industry continued during the period. The plan intended to continue research works for the development of technology in the areas of low cost construction and use of local raw materials. Emphasis was given to maximize the use of local technology, expertise, and skills and to explore and develop new and appropriate technology as well. 
DOI: 10.14807/ijmp.v7i1.376

\section{h) Eighth Plan (1992 - 1997)}

It was assumed that advanced technology and institutional reforms would be made indispensable tools of support to private sector and organizations down to the village level. Dissemination of appropriate technology in agriculture sector was continuous in the plan as well.

In order to accelerate the technology transfer process, it was aimed to increase participatory role of agricultural research in training and communication programs. Some joint venture and technology promotion institutions were expected to be set up with a view to providing support to manufacture energy related equipment. Indigenous labor, skill and resource as well as foreign investment and technology were desired to utilize in development of hydropower. Rural telecommunication services were intended to be provided by adopting appropriate technology to the geographical features of the country.

Foreign investment was expected to be increased for maximum utilization of managerial and technical skills, modern technology, and in the process of promoting industries. The Plan made institutional arrangements to familiarize the cottage and small-scale industries with market, technology, skills, and the like.

There was an intention to establish technology transfer and development center to collect and publish statistics related to technology development and transfer, and to assist technically in the selection, evaluation, and replication of suitable technology. Technical schools started to be established in different parts of the country. The plan included activities like development of national information bank and network system, social communication program, and development of technology for the poor.

The plan continued with the objectives of developing science and technology in a way that it could support all-round development of the nation; supporting rural development sectors such as agriculture, cottage and small scale industries by enhancing scientific and technological capabilities available in the country; and encouraging import of foreign technologies that have a direct bearing on the country's economic development.

Major programs of the Plan included the management and expansion of infrastructure necessary to enhance the potentials of scientific research and 
DOI: 10.14807/ijmp.v7i1.376

development; promotion of technology transfer and replication; productivity of quality workforce; and publicity and dissemination of technology.

The Plan further attempted to promote technology transfer and replication in agriculture, industry, transport, communication, and construction, and if necessary, it was intended to permit for import of such technology. The concerned government, private and non-government organizations, and institutions were encouraged to undertake this task.

\section{i) Ninth Plan (1997 - 2002)}

Priority to communication and information technology was given more in the Plan in order to adopt the changing technology. It was essential to launch programs such as experiment and development of indigenous and advanced technology, reforms in education, and development of information and communication infrastructure. Similarly, development of indigenous technology and adoption of new and advanced technology were also in priority.

Establishment of an Information Technology (IT) Park and production and export of software at lower cost were other attractions of the Plan. Emphasis was continuous on adoption of employment-oriented technology. Appropriate technology for food industries in the areas of collecting, grading, processing, and marketing was desired to develop even after several trials and findings.

Attention was given to the environment and pollution control. It was planned that National Broadcasting Authority (NBA) would be established and an effective broadcasting of radio and television would be arranged. It was desired to prepare national information infrastructure for contributing to the development of agriculture, health, education, tourism, and commerce sectors through the information technology park and information highway.

Focus of the objectives were maintaining sustainability in economic, social, cultural and environmental perspectives; improving traditional technologies; developing and transferring appropriate rural technology; developing and transferring advanced technology in order to reduce foreign trade deficit; improving teaching and learning in higher education; improving energy use efficiency; expanding hydro and meteorological services; and emphasizing the research and development activities. 
DOI: 10.14807/ijmp.v7i1.376

System of developing science and technology sectors was expected to be initiated in the districts, municipalities, and village development committees. A twenty-year science and technology perspective plan was likely to be formulated during the plan period; application of hydro, solar and wind energy was encouraged to replace imported energy through the adaptive study, research and development and commercialization of energy technology.

Advanced technology transfer and development programs were intended to be conducted through the agencies that were interested to produce goods having comparative advantage, alternative energy use was emphasized; and arrangement of subsidy was also be made for those efforts that were developing and transferring for export and/or trade promotion.

\section{j) Tenth Plan (2002 - 2007)}

This Plan included the use of high-tech technology in rural area. Micro and rural industrial technology, telecommunication, and information technology, appropriate and environment friendly technology, agricultural technology, biotechnology, labor-intensive technology in rural areas were some areas of concentration.

Technology related with geographic information system was intended to apply to prepare soil database. Use of technology was considered instrumental in fulfilling basic needs, alleviating poverty, promoting income generating activities, generating employment opportunities, conserving environment and natural resources. The plan wished for making children, women, and deprived section economically independent with science and technology.

A national level electronic network of science and technology information centers was in priority to integrate the scattered science and technology libraries and records across the country. Commercialization of alternative energy technologies and reducing the dependence on imported energy through the planned technology development and expansion programs were also included in the plan.

\section{k) Three Years Interim Plan (2007 - 2010)}

The industry sector faced problems in technology transfer and absorption. Rural information centers were started to be established in different parts of the 
DOI: 10.14807/ijmp.v7i1.376

country. Promotion of indigenous skill, efficiency, and technology became the conditions of foreign aid acceptance. Priority had been accorded to industries, professions and programs based on labor-intensive technology to generate employment opportunities in rural areas.

The agricultural production system would be made more competitive and commercial through the extension of appropriate agricultural technology. Promotion of rainwater harvesting in rural areas was emphasized. Utilization of information technology in order to make farmers capable of making decision by disseminating advanced technology and market information to the rural levels emphasized.

Multi sector technology development trials were expected to carry out. Agriculture research and technology transfer got high priority in public investments. National Agriculture Research and Development Fund (NARDF) was intended to be involved to develop and expand technologies for short terms with social mobilization.

Department of Food Technology and Quality Control (DFTQC) was expected to be extended to districts to render the service of maintaining food hygiene and safety. Introduction of Safety Management System by utilizing advanced technology of international standard in the civil aviation sector was proposed to ensure the flight safety. The concept of a working system of cleaner production technology and green productivity was also highlighted. The Plan had mentioned the physical improvement of urban and rural houses by using earthquake resistant technology.

Use of information technology in government works was intended to be expanded, and provisions had been made to give legal recognition to e-information dissemination. Quality human resource in the science and technology sector was also in priority.

Preservation of indigenous technology and its research as well as development of competitive capability, reduction of the digital divide and prevention of brain drain was noticed some of the major challenges to the country.

\section{I) Three Years Plan (2010 - 2013)}

There was quite satisfactory improvement had been made in adoption of solar energy technology, but nominal progress in adoption of other sources of alternative 
energy. Employment creation was a major criterion in selection of investment projects.

This Plan emphasized for adoption of information technology in the government revenue offices including customs. Adoption of new technology in food laboratory, promotion of technology to minimize the impact of climate change, transfer of technology through electronic communication media, establishment, and operation of technology development fund with collaboration of private and cooperative sectors, technology transfer through economic diplomacy, promotion, and extension of telecommunication services for technology transfer were some other attractions of the plan.

Use of information technology in corporate governance, emphasis on research and development of information technology, encouragement of construction and operation of electronic Hardware Technology Park, promotion of information Technology Park, establishment of Public Key Infrastructure (PKI) data center as well as government integrated data center were other focused areas of the Plan.

There was emphasis on public-private partnership for the development of science and technology as well as the study and use of biotechnology, information technology, Nano technology, nuclear technology, and space technology. Establishment of space science and technology center, nuclear technology center, biotechnology research center, and preparation of Bioinformatics database were a few ambitions of the Plan.

\subsection{Technology Policies and Sectorial Priorities}

The country adopted a couple of policies in line to its planning priorities set by the national periodic plan documents. Foreign Investment and Technology Transfer act 1982, National Science and Technology Policy 1988, Science and Technology Policy 1990, Information Technology Policy 2000, Science and Technology Policy 2004, Bio-technology Policy 2006; Rural Energy Policy 2006; Technology Directives 2006 were a couple of major technology related policy initiatives and changes in the country.

This study has categorized the sectorial priorities of the periodic plan documents into three main categories- research and infrastructure development, socioeconomic development, and good governance and compliance (see 
DOI: 10.14807/ijmp.v7i1.376

Table 1). Research and infrastructure category included road transport; electricity and power; irrigation; information and communication facilities; housing and urban development; environment, science and technology as well as research and development activities. Education, culture and sports; health, population, water supply and sanitation; children; youth; senior citizens; natural disaster management; local development; non-governmental organizations; and human resource development, agriculture; cooperatives; land reform and management; forest and soil conversation; tourism and civil aviation; industry; commerce; supply management; labor management and employment; and transport management are included in socioeconomic development category.

Decentralization and deregulation; planning and statistical system development; and implementation, monitoring, evaluation and reporting included in the category of governance and compliance.

Table 1: Sectorial priorities concerning technology diffusion in Nepal

\begin{tabular}{|c|c|c|c|}
\hline Plan & Research and infrastructure & Socioeconomic development & Governance and compliance \\
\hline 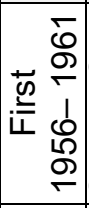 & $\begin{array}{l}\text { Mineral and hydropower } \\
\text { exploration; technical } \\
\text { institution establishments; } \\
\text { investment in technology and } \\
\text { capital equipment }\end{array}$ & $\begin{array}{l}\text { Technical training; provision of } \\
\text { scholarships; emphasis on } \\
\text { agricultural and forestry } \\
\text { education }\end{array}$ & $\begin{array}{l}\text { Desire of competent administrative } \\
\text { and technical personnel, formation } \\
\text { of technical committees and } \\
\text { provision of advisors }\end{array}$ \\
\hline 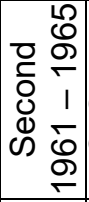 & $\begin{array}{l}\text { Focus on engineering inst } \\
\text { establishment and } \\
\text { development }\end{array}$ & $\begin{array}{l}\text { Technical training assurance; } \\
\text { establishment of experimental } \\
\text { farms and livestock centers; } \\
\text { technical training assurance }\end{array}$ & $\begin{array}{l}\text { Technical training to the personnel } \\
\text { at the government agencies, and the } \\
\text { Panchayats were made more } \\
\text { effective in technology transfer }\end{array}$ \\
\hline 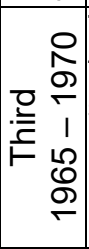 & $\begin{array}{l}\text { Technical assistance for } \\
\text { transport development, } \\
\text { storage, and private sector }\end{array}$ & $\begin{array}{l}\text { Intended to replace the primitive } \\
\text { technology in agriculture; } \\
\text { technical assistance for private } \\
\text { sector development; emphasis } \\
\text { on vocational education and } \\
\text { adult education }\end{array}$ & $\begin{array}{l}\text { Considered Panchayats as a vehicle } \\
\text { for technology transfer in social } \\
\text { sectors; decentralization prioritized; } \\
\text { coordination among the } \\
\text { development programs emphasized }\end{array}$ \\
\hline 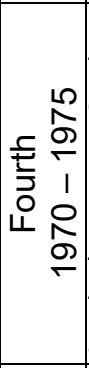 & $\begin{array}{l}\text { Focus on vocational and } \\
\text { training centers } \\
\text { establishment; nucleus seed } \\
\text { production program; food } \\
\text { research programs, forestry } \\
\text { programs; feasibility survey } \\
\text { for roads; expansion of } \\
\text { telecommunication facilities } \\
\text { and industrial services }\end{array}$ & $\begin{array}{l}\text { Foreign trade considered as a } \\
\text { mean of obtaining technical } \\
\text { know-how; leader farmer } \\
\text { training program; provision of } \\
\text { JTs and JTAs }\end{array}$ & $\begin{array}{l}\text { Maintaining records of technical } \\
\text { manpower realized; foreign technical } \\
\text { assistance sought; labor intensive } \\
\text { technology and indigenous } \\
\text { resources emphasized; }\end{array}$ \\
\hline 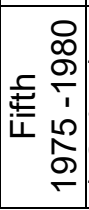 & $\begin{array}{l}\text { Emphasis on strengthening } \\
\text { the organizational network; } \\
\text { agricultural research and } \\
\text { education; promotion of } \\
\text { technology center }\end{array}$ & $\begin{array}{l}\text { Extensive rural work programs; } \\
\text { focus on manpower } \\
\text { development in technical field }\end{array}$ & $\begin{array}{l}\text { Encouragement of labor intensive } \\
\text { programs and technology }\end{array}$ \\
\hline
\end{tabular}




\begin{tabular}{|c|c|c|c|}
\hline Plan & Research and infrastructure & Socioeconomic development & Governance and compliance \\
\hline 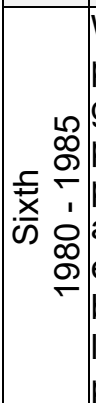 & $\begin{array}{l}\text { Wish-for the studies on } \\
\text { production and use of bio- } \\
\text { gas, solar energy, wind } \\
\text { power, and natural gas; } \\
\text { programs on drug research } \\
\text { and development; cost } \\
\text { effective technology in } \\
\text { building small hydel projects; } \\
\text { labor intensive technology } \\
\text { promotion in road building }\end{array}$ & $\begin{array}{l}\text { Efforts to disseminate } \\
\text { technology that improves the } \\
\text { breed of calve, bull, buffalo, } \\
\text { goat, sheep, chicken, fish, etc. } \\
\text { Efforts on the improvement of } \\
\text { production technology of the } \\
\text { cottage industries; encourage } \\
\text { foreign technology and capital } \\
\text { in extraction of mineral } \\
\text { deposits }\end{array}$ & $\begin{array}{l}\text { Emphasis on the use of local skills } \\
\text { and technology; use of locally } \\
\text { available construction materials; } \\
\text { determination of national science } \\
\text { and technology objective, policy and } \\
\text { programs }\end{array}$ \\
\hline 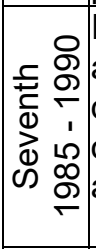 & $\begin{array}{l}\text { Intended to upgrade science } \\
\text { and technology capabilities; } \\
\text { desire to reduce dependency } \\
\text { on agriculture; shifting } \\
\text { attention to industrial sectors }\end{array}$ & $\begin{array}{l}\text { Desire of high technology and } \\
\text { skills development to expand } \\
\text { export; enlarge international } \\
\text { assistance and its participation } \\
\text { in the field of science and } \\
\text { technology }\end{array}$ & $\begin{array}{l}\text { Intended to increase awareness on } \\
\text { the usefulness of science and } \\
\text { technology; maximum use of local } \\
\text { technology, know-how and skills } \\
\text { emphasized }\end{array}$ \\
\hline 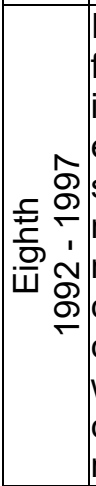 & $\begin{array}{l}\text { Institutional arrangement to } \\
\text { familiarize small and cottage } \\
\text { industries with technology; } \\
\text { establishment of technical } \\
\text { schools; development of } \\
\text { national information bank and } \\
\text { network system; } \\
\text { computerization of } \\
\text { commercial banks; research } \\
\text { works on low cost } \\
\text { construction and use of local } \\
\text { raw materials }\end{array}$ & $\begin{array}{l}\text { Agriculture extension program } \\
\text { in outreach; foreign investment } \\
\text { and technology transfer for } \\
\text { hydropower development; rural } \\
\text { communication services; } \\
\text { mineral exploration and } \\
\text { development; social } \\
\text { communication program, } \\
\text { development of technology for } \\
\text { the poor }\end{array}$ & $\begin{array}{l}\text { Priority in dissemination of } \\
\text { appropriate technology in agriculture } \\
\text { sector; advance technology and } \\
\text { institutional reforms; promotion of } \\
\text { technology transfer and replication; } \\
\text { publicity and dissemination of } \\
\text { technology }\end{array}$ \\
\hline 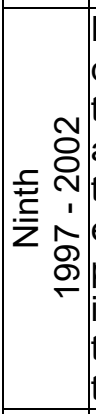 & $\begin{array}{l}\text { Emphasis on the } \\
\text { development of indigenous } \\
\text { technology; development of } \\
\text { adaptive and advanced } \\
\text { technology; provision for the } \\
\text { establishment of IT park; } \\
\text { preparation of national } \\
\text { information infrastructure; } \\
\text { twenty years science and } \\
\text { technology prospective plan }\end{array}$ & $\begin{array}{l}\text { Emphasis on communication } \\
\text { and information technology; } \\
\text { adaption of environment } \\
\text { conducive and labor intensive } \\
\text { construction technology; use of } \\
\text { appropriate technology in foods } \\
\text { processing; rural technology } \\
\text { development and dissemination } \\
\text { program }\end{array}$ & $\begin{array}{l}\text { Intention of reform in education; } \\
\text { emphasis on employment oriented } \\
\text { technology; environment pollution } \\
\text { control initiatives; encouragement } \\
\text { for application of hydro, solar and } \\
\text { wind energy }\end{array}$ \\
\hline 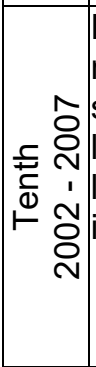 & \begin{tabular}{|l|} 
Desire of an electronic \\
networking of scattered \\
science and technology \\
libraries and records; national \\
level science and technology \\
information center formation
\end{tabular} & $\begin{array}{l}\text { Intention of high-tech in rural } \\
\text { area; adoption of agricultural } \\
\text { technology, bio-technology, } \\
\text { micro and rural industrial } \\
\text { technology, telecommunication } \\
\text { and information technology; } \\
\text { environment friendly } \\
\text { technology; commercialization } \\
\text { of alternative energy technology }\end{array}$ & $\begin{array}{l}\text { Priority for the technology that } \\
\text { promotes employment opportunities; } \\
\text { use of geographic information } \\
\text { system; use of labor-intensive and } \\
\text { environment friendly technology; } \\
\text { technology directives }\end{array}$ \\
\hline 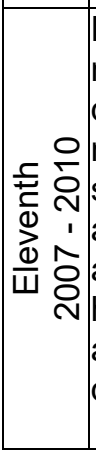 & \begin{tabular}{|l|} 
Rural information center; \\
multi-sector technology \\
development; land \\
management technology; \\
safety management system in \\
aviation; concept of science \\
and technology university; \\
health management research \\
and technological \\
development institutions
\end{tabular} & $\begin{array}{l}\text { Self-employment promotion; } \\
\text { employment opportunities in } \\
\text { rural areas; rain water } \\
\text { harvesting in rural areas; } \\
\text { physical improvement of urban } \\
\text { and rural houses; development } \\
\text { of high level human resources, } \\
\text { bio-technology; information } \\
\text { technology; institutional } \\
\text { capability enhancement and } \\
\text { strengthening program }\end{array}$ & $\begin{array}{l}\text { Technology dissemination; } \\
\text { conditions to foreign aid- indigenous } \\
\text { skill, efficiency and technology; } \\
\text { cleaner production technology, and } \\
\text { green productivity; use of } \\
\text { information technology in } \\
\text { government works }\end{array}$ \\
\hline
\end{tabular}


DOI: 10.14807/ijmp.v7i1.376

\begin{tabular}{|c|c|c|c|}
\hline Plan & Research and infrastructure & Socioeconomic development & Governance and compliance \\
\hline 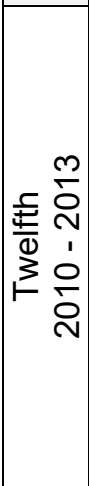 & $\begin{array}{l}\text { Concern to climate change; } \\
\text { telecommunication } \\
\text { considered as a major vehicle } \\
\text { of technology transfer; } \\
\text { expansion of IT facilities } \\
\text { emphasized; concept of } \\
\text { electronic hardware } \\
\text { technology park; study and } \\
\text { use of bio-technology, } \\
\text { Nanotechnology, nuclear } \\
\text { technology, and space } \\
\text { technology }\end{array}$ & $\begin{array}{l}\text { Adoption of solar energy; } \\
\text { employment creation } \\
\text { emphasized; technology } \\
\text { development fund; } \\
\text { Bioinformatics database } \\
\text { preparation }\end{array}$ & $\begin{array}{l}\text { Emphasis on the adoption of IT } \\
\text { across government revenue offices; } \\
\text { priority in food technology adaption; } \\
\text { technology transfer through } \\
\text { economic diplomacy; use of } \\
\text { information technology in corporate } \\
\text { governance }\end{array}$ \\
\hline
\end{tabular}

Source: The national periodic plan documents of Nepal

\subsection{Structural Settings}

Unplanned efforts of technology diffusion were dominating until the end of the first half of twentieth century. Planned efforts started to take place in the country only from the beginning of the second half of the century (also see Erro! Fonte de referência não encontrada.). The interrelationship among the organizations involved in technology education, training, research and development; national planners and regulators including national planning commission, ministries, and departments; supporting industries and intermediaries including telecommunication and Internet service providers, banking and financial institutions as well as accessories, parts and support service providers; and technology suppliers and the technology adopters is considered structural settings for technology diffusion.

Table 2- Selected organizations working on technology diffusion

\begin{tabular}{|c|l|l|}
\hline From & \multicolumn{1}{|c|}{ Institutions } & \multicolumn{1}{|c|}{ Major works/projects } \\
\hline 1951 & Department of Agriculture (DOA) & $\begin{array}{l}\text { Food security, agricultural productivity; screening and } \\
\text { standardization of the technologies }\end{array}$ \\
\hline 1951 & Department of Industry (DOI) & $\begin{array}{l}\text { Technology and environment, foreign investment and } \\
\text { technology transfer, technology development; industrial } \\
\text { data system improvement and monitoring }\end{array}$ \\
\hline 1969 & $\begin{array}{l}\text { Center for Economic Development } \\
\text { and Administration (CEDA) }\end{array}$ & $\begin{array}{l}\text { Socioeconomic and administrative development } \\
\text { assisting/working with the policy makers }\end{array}$ \\
\hline 1972 & The Institute of Agriculture and & $\begin{array}{l}\text { Education, research and technology transfer in the } \\
\text { agriculture sector }\end{array}$ \\
\hline 1972 & Institute of Medicine (IOM) & $\begin{array}{l}\text { Education and training to middle and high level } \\
\text { professional in forestry and natural resources } \\
\text { management }\end{array}$ \\
\hline 1972 & Institute of Engineering (IOE) & $\begin{array}{l}\text { Research, education and services in the health sector } \\
\text { Research, education and training in engineering; } \\
\text { consultancy services }\end{array}$ \\
\hline 1973 & $\begin{array}{l}\text { Department of Cottage and Small } \\
\text { Industries (DOCSI) }\end{array}$ & $\begin{array}{l}\text { Business incubation; technology diffusion and } \\
\text { consultation services }\end{array}$ \\
\hline 1977 & $\begin{array}{l}\text { Research Center for Applied } \\
\text { Science and Technology (RECAST) }\end{array}$ & $\begin{array}{l}\text { Renewable energy; bio-technology; appropriate } \\
\text { technology; plant science; natural product utilization; } \\
\text { low cost building materials }\end{array}$ \\
\hline 1982 & Nepal Academy of Science and & Advancement of science and technology for all-round \\
\hline
\end{tabular}


ISSN: 2236-269X

DOI: 10.14807/ijmp.v7i1.376

\begin{tabular}{|c|c|c|}
\hline & Technology (NAST) & $\begin{array}{l}\text { development; preservation and further modernization of } \\
\text { indigenous technologies; identification and facilitation of } \\
\text { appropriate technology transfer; promotion of research } \\
\text { in science and technology }\end{array}$ \\
\hline 1989 & $\begin{array}{l}\text { Institute of Science and Technology } \\
\text { (IOST) }\end{array}$ & $\begin{array}{l}\text { Research, education, training, publications and advisory } \\
\text { services in the area of science and technology }\end{array}$ \\
\hline 1991 & $\begin{array}{l}\text { Nepal Agricultural Research Council } \\
\text { (NARC) }\end{array}$ & $\begin{array}{l}\text { Research on agriculture; coordination, monitoring and } \\
\text { evaluation of agricultural research activities }\end{array}$ \\
\hline 1992 & $\begin{array}{l}\text { Asia Network for Sustainable } \\
\text { Agriculture and Bio resources } \\
\text { (ANSAB) }\end{array}$ & $\begin{array}{l}\text { Biodiversity conservation and livelihood improvement in } \\
\text { South Asia }\end{array}$ \\
\hline 1996 & $\begin{array}{l}\text { Industrial Enterprise Development } \\
\text { Institute (IEDI) }\end{array}$ & $\begin{array}{l}\text { Need-based programs to develop technical know-how } \\
\text { and skills }\end{array}$ \\
\hline 1998 & $\begin{array}{l}\text { Nepal Telecommunication Authority } \\
\text { (NTA) }\end{array}$ & Regulating telecommunication sector \\
\hline 1998 & $\begin{array}{l}\text { Micro-Enterprise Development } \\
\text { Program (MEDEP) }\end{array}$ & $\begin{array}{l}\text { Appropriate technology and quality assurance, micro- } \\
\text { enterprise management information system; } \\
\text { entrepreneurship development; and others }\end{array}$ \\
\hline 2000 & $\begin{array}{l}\text { Department of Food Technology and } \\
\text { Quality Control (DFTQC) }\end{array}$ & $\begin{array}{l}\text { Development and dissemination of appropriate food } \\
\text { (processing) technology }\end{array}$ \\
\hline 2005 & $\begin{array}{l}\text { Ministry of Science, Technology and } \\
\text { Environment (MOSTE) }\end{array}$ & $\begin{array}{l}\text { Program of action on climate change; } \\
\text { resilience; technology needs assessment; mountain } \\
\text { initiative; environmental impact assessment; and others }\end{array}$ \\
\hline
\end{tabular}

Source: The webpages of respective organizations

Technology diffusion requires a strong network of reciprocal interdependence among the organizations involved in the diffusion process. Individual organizations in isolation finds hard to diffuse technology in an effective and efficient way because of a number of shortcomings in the areas of technology development, transfer, and adoption along with difficulties in supporting multiple actors. Organizations may be working in all the stages of technology diffusion ranging from the technology development, adoption to the disposition.

The organizations under study were quite tall and hierarchical instead of flat and networked as required for the diffusion of technology. The traditional pyramid typestructure of adopting organizations and all other organizations involved in the area of technology development and diffusion was not instrumental in transforming the national technology planning priorities in practices. The plan documents were not acknowledging the urgency of control and monitoring in the establishment and operationalization of the organizations in the field of technology. There was absent of priorities about the carrier and linkage between technology planning priorities and the technology developing and adopting agencies in the country. 
DOI: 10.14807/ijmp.v7i1.376

The government of Nepal adopted liberal economic policy from the very beginning of 1990s, and encouraged private sector for their active participation in technology development and transfer; but the government did not regulate the registration and formation of the organizations in consideration of monitoring thereof. In absence of technology regulator in the country, haphazard entry or no entry of organizations into the economy become obvious. Functional areas of the organizations already established as such could not address and carry the technology planning priorities to the real adopters of it. Ultimately, the organizational settings could not assimilate the technology planning priorities and the subsequent development and diffusion process of it.

\section{DISCUSSION}

Agriculture sector was one of the priority areas for technology development and diffusion in Nepal. Most of the farmers/cultivators were illiterate and they were reluctant/hesitant to be changed from their traditional system of cultivation to the modern one.

Almost all the development projects were based on technical assistance of foreign countries. Consequently, the materials, parts, and expertise required for the projects were accordingly foreign. Foreign technology transfer could not promote employment level because of a slow technology absorption capability of the country.

The plan documents could not determine the priority areas specifically for locally available technology development and other supporting areas, if there was any foreign technology transfer. There was haphazard shift in policy shifts as well, for an instance, the seventh plan intended to shift focus from an agriculture based economy to industry based economy in absence of sufficient evidence of agriculture based economyfailure at one part and in absence of similar evidence for success of industry based economy on the other.

The ninth plan acknowledged that traditional technology, skill, and knowledge were disappearing gradually in the country, which means the past efforts of indigenous technology development were ineffective despite the continuous attempts of developing it. Without making reasonable asessment on the disappearing of indigenous technology, the tenth Plan intended for application of high-tech in rural 
DOI: 10.14807/ijmp.v7i1.376

area as well that forther contradicted the commitment made to develop and promote indigenous technology from the beginning of the planning period.

Promotion of indigenous skill, efficiency, and technology became the conditions of foreign aid acceptance, but the donor funded project specifications included internationally standardized technology, products, and services thereof. Similarly, employment creation had been made one major criterion in the selection of investment projects, but the statistics of about 500,000 youths leaving the country every year in search of employment in foreign countries (BHATTARAI, 2010) could not support the effectiveness of the government's policy of acceptance and selection of only projects that provide employment first.

There was adoption of information technology in the government revenue offices including customs. However, the respondents clearly indicated a number unwanted scenarios like delay in customs clearance, unnecessary and unethical behaviors at the government's revenue offices; avoiding the role of independent researchers and professionals in national technology development processes; prevalence of supremacy of the politicians and civil servants in the technology policy formulation and implementation; tendency of the government officials especially high ranking ones just to use their power instead of the use of their expertise in due course of providing services to ordinary people and organizations as well as in the areas of implemention of the policies, acts, rules and regulations for the development and diffusion of technology.

There was continuous emphasis on the technology dissemination in absence of provisions of appropriate mechanism for such dissemination. The mechanisms, known as structural settings and technology planning priorities were in parallel. There were a few attempts in the area of institutional capability enhancement during the planned period. However, such attempts could not establish appropriate and effective linkage across the actors in the process of technology diffusion. The linkage among the organizations/institutions engaged in technology assessment, research and development, technology adaptation, and the supporting service providers would have been facilitating to defuse technology in the country, if such linkage were established. 
DOI: 10.14807/ijmp.v7i1.376

Science and technology system in societies needs to establish a strong link between knowledge creation and social demands. The link is required to strengthen the process of addressing social demands and solving their problems. This study argues that organizational setting is also an interface of technological advancement in a country because it is linking the initiatives of technology development, utilization, and diffusion in the society.

The study found that absence of technology regulating mechanisms in the country;increasing dependence on foreign technology by neglecting the indigenous one; and emphasis on search of international economic aid than developing the selfreliance capability were making the parallel standing of the organizational settings and technology diffusion in Nepal.

\section{CONCLUSIONS}

This study concludes with identification of structural immunity to technology diffusion in Nepal. In appropriate balance between the continuous efforts for promotion of indigenous technology at one part and encouragement to foreign investment and technology transfer on the other could not bring significant improvements in the areas of technology development, but the efforts made near extinction of indigenous technology instead. Contradictory commitments of the plans like emphasis to the labor-intensive technology/projectsand encouragement for import of advanced technology did not follow distinctive areas in the technology development interventions in the country

There was incongruence between organizational settings and the periodic planning priorities in absence of technical organizations cooperation coordination mechanism for technology development, diffusion, and absorption. The planning priorities could not enhance the alignment of the structural settings with the requirement for technology transfer and diffusion in the country. More specifically:

- Agriculture sector was immune to technology diffusion. The farmers were habitual with traditional technology/processes and they were unable to adopt new technology in absence of socioeconomic compatibility for their efforts and outcomes; 
INDEPENDENT JOURNAL OF MANAGEMENT \& PRODUCTION (IJM\&P)

http://www.ijmp.jor.br

v. 7, n. 1, January - March 2016

ISSN: 2236-269X

DOI: 10.14807/ijmp.v7i1.376

- The industrial sector was immune to technology diffusion. There was incompatibility with hardware, software, brainware, know-how and knowwhy;

- Educational sector was immune to technology diffusion. The instructors and students both were uncomfortable with the new course contents and teaching pedagogy thereof;

- Government sector was immune to technology diffusion. Government officials were more authoritarian instead of being ethically cooperative consultant;

- Political sector was immune to technology diffusion. The political leaders were engaged in self-flattering and blame games, instead of commitmets and determination to the national interests of technology development;

- Compliance sector was immune to technology diffusion. Good (corporate) governance was a taken as a compulsion and ethical business behavior was questioning; and

- Organizational setting was immune to technology diffusion. Solidarity was mechanistic with a rigid authority hierarchy in parallel of national planning priorities.

The planned efforts remained unable to identify what type and level of indigenous technology would be in effect to what extent. There were no clear demarcations for new technology development and existing technology enhancement. The technology planning priorities were confined within the plan documents rather than fitting them into the structural settings. The periodic planning priorities did not acknowledge the urgency of a strong congruence between the national technology priorities and the immune organizational settings in the country.

Technology diffusion is strictly required to be deliberately coordinated effort of the actors in the structural settings with their strong interdependence. Unplanned hierarchical structural settings of mainstream organizations in an economy stands as a barrier in the process of technology diffusion.

Advancement in telecommunication facilities and access to the Internet has shadowing the hierarchical taboos in most of the organizations in real sense. 
DOI: $10.14807 /$ ijmp.v7i1.376

Adoption of information technology shall help to maintain the congruence at one part and the same will facilitate in order to overcome the barrier of structural immunity to technology diffusion on the other part. Immunity of the policy makers and policy adopters to change only strengthens structural immunity to technology diffusion, which is strongly opposing the endeavior of technology advancement.

\section{REFERENCES}

ANSAB. (2011). Welcome. Retrieved June 20, 2013, from Asia Network for Sustainable Agriculture and Bioresources: http://www.ansab.org/

ASTLEY, G. W.; VAN DE VEN, A. H. (1983, June). Central Perspectives and Debates in Organization Theory. Administrative Science Quarterly, v. 28, n. 2, p. 245-273.

CEDA. (2013). Introduction. Retrieved June 19, 2013, from Center for Economic Development and Administration: http://www.tribhuvanuniversity.edu.np/index.php?option=com_content\&view=article\&id=184. .

DFTQC. (2013). Brief introduction. Retrieved June 20, 2013, from Department of Food Technology and Quality Control: http://www.dftqc.gov.np/

DOA. (2013). Objectives. Retrieved June 16, 2013, from Department of Agriculture: http://www.doanepal.gov.np/content.php?id=129

DOCSI. (2012). Welcome to the website of department of cottage and small industries. Retrieved June 20, 2013, from Department of Cottage \& Small Industries: http://www.dcsi.gov.np/dcsi_en/index.php

DOI. (2013). Introduction. Retrieved June 20, 2013, from Department of Industry: http://www.doind.gov.np/

IAAS. (2013). Introduction. Retrieved June 19, 2013, from Institute of Agriculture and Animal Science.

IEDI. (2013). Objectives of IEDI. Retrieved June 19, 2013, from Industrial Enterprise Development Institute: http://www.iedi.org.np/Objectives.html

IOE. (2013). Introduction. Retrieved June 19, 2013, from Institute of Engineering: http://www.tribhuvan-

university.edu.np/index.php?option=com_content\&view=article\&id=175

IOF. (2013). About. Retrieved June 20, 2013, from Institute of Forestry: http://www.iof.edu.np/about_iof.htm

IOM. (2009). Welcome to IOM. Retrieved June 19, 2013, from Institute of Medicine: http://www.iom.edu.np/

IOST. (2013). Vision and objectives. Retrieved June 20, 2013, from Institute of Science and Technology: http://www.tribhuvanuniversity.edu.np/index.php?option $=$ com_content\&view=article\&id $=174$

JOSHI, D. R. (2007). Science and technology policy in Nepal. Retrieved June 19, 2013, from Nepal S\&T Policy Research Conference: www.mis.nsf.ac.lk/.../Nepal

KEGAN, R.; LASKOW LAHEY, L. (2009). Immunity to change: How to overcome 
DOI: $10.14807 /$ ijmp.v7i1.376

it and unlock potential in yourself and your organization. Boston: Harvard Business Press.

MEDEP. (2008). What we do. Retrieved June 17, 2013, from Micro-Enterprise Development Program: http://www.medep.org.np/index.php?page=page\&id=1

MOSTE. (2013). About us. Retrieved June 15, 2013, from Ministry of Science, Technology and Environment: http://moste.gov.np/ministry/about_us

NARC. (2007). About NARC. Retrieved June 19, 2013, from Nepal Agricultural Research Council: http://narc.gov.np/about/index.php\#2

NAST. (2009). Objectives. Retrieved June 18, 2013, from Nepal Academy of Science \& Technology: http://www.nast.org.np/page.php?id=36

NTA. (2012). Welcome to NTA website. Retrieved June 18, 2013, from Nepal Telecommunications Authority: http://www.nta.gov.np/en/home-en/12-english/page/1welcome

PANDEY, S.; YADAMA, G. N. (1992). Community development programs in Nepal: a test of diffusion of innovation theory. Social Science Review, v. 66, n. 4, p. 582-597.

RECAST. (2013). Introduction. Retrieved June 18, 2013, from Research Center for Applied Science and Technology: http://www.tribhuvanuniversity.edu.np/index.php?option=com_content\&view=article\&id=187\&ltemid=244

SINGH, R. M.; BHUJU, D. R. (2001). Development of science and technology in Nepal. Science, TEchnology \& Society, v. 6, n. 1, p. 159-178. 